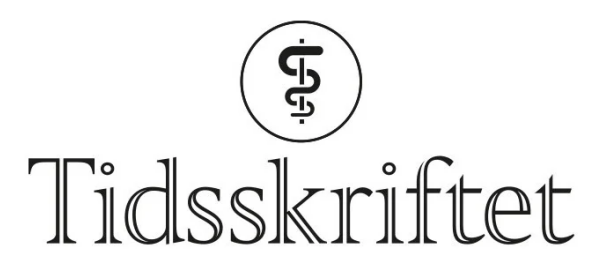

DEN NORSKE LEGEFORENING

\title{
Når mer kjærlighet ikke er svaret
}

\section{ANMELDELSER}

\section{ALV A. DAHL}

Oslo universitetssykehus, Radiumhospitalet

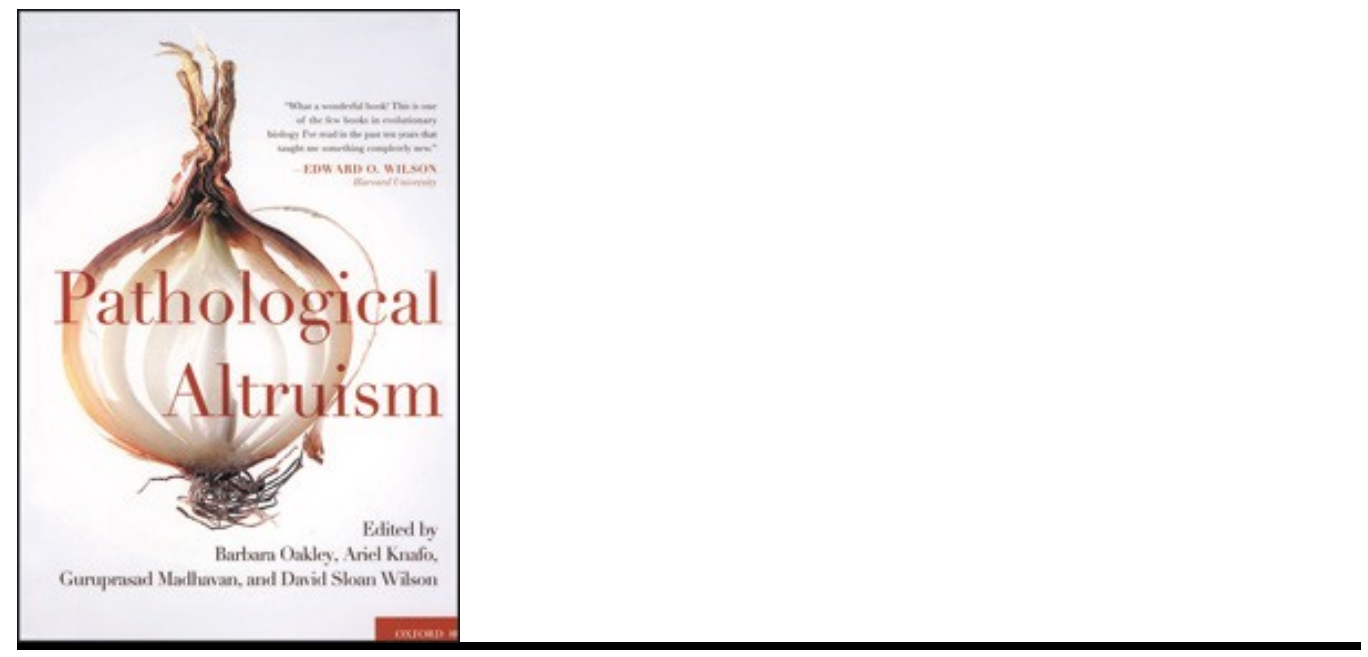

Oakley, Barbara

Knafo, Ariel

Madhavan, Guruprasad

Pathological altruism

465 s, tab, ill. Oxford University Press, 2012. Pris GBP 35

ISBN 978-0-19-973857-1

Altruisme er definert som en uselvisk og offervillig holdning og handling overfor andre, og er som sådan en høyt verdsatt egenskap i sosiale sammenhenger. Men som svenskene sier, «lagom är best», og derfor finnes det også patologisk altruisme, der det enten er for lite eller for mye av dette personlighetstrekket. For lite altruisme kalles gjerne egoisme, men denne teksten er ikke så opptatt av slike væremåter. Snarere handler den om for mye altruisme, som enten skader dem som er gjenstand for altruismen (ofrene), eller dem som utøver den. Patologisk altruisme rammer enten dem man prøver å hjelpe, eller hjelperen som i sin iver går for langt. Det første handler om å bli kvalt av godhet, og det andre om at godheten går 
ut over utøveren. Et eksempel på det siste er legen Elisabeth Kübler-Ross, som mange vil huske for Før livet ebber ut (1). Hun forsaket alt ellers i livet for sine døende pasienter, noe hennes mann og barn bebreidet henne for, og som førte til en ganske spesiell form for legepraksis.

Forfatterne kan derfor ha et budskap til kolleger som på ulike måter strekker seg for langt for pasientene sine, men problemet er jo ofte at de ikke er klar over det selv. Derfor er boken kanskje av særlig interesse for psykiatere og kliniske psykologer som driver kollegial veiledning, og for leger som følger Terents' berømte utsagn: "Jeg er et menneske, og intet menneskelig er meg fremmed.»

I de 31 kapitlene nærmer forfatterne seg patologisk altruisme fra psykologisk, psykiatrisk, sosiologisk, nevrobiologisk, kulturelt og evolusjonsmessig perspektiv. Kapitlene varierer fra det strengt empiriske til det personlig impresjonistiske. Tre av redaktørene er amerikanere, og en er fra Israel, mens de 44 forfatterne representerer en bred internasjonal sammensetning. Ingen er imidlertid fra Skandinavia.

Boken er relativt teoritung, og det tok meg atskillige sider før jeg hadde en klar forståelse av hva som er normal, sunn altruisme - i motsetning til patologisk altruisme. Til gjengjeld skjønte jeg etter hvert at vi kanskje har et naivt og ureflektert Kardemomme-forhold til normal altruisme: «Man skal ikke plage andre, man skal være god og snill, og for øvrig kan man gjøre hva man vil.» De som ikke har forstått at Moder Teresa var forstyrret eller at Kronprinsen med kravet om mer kjærlighet gir galt tilsvar til ondskapen, blir klokere av denne boken.

\section{LITTERATUR}

1. Kübler-Ross E. Før livet ebber ut. Oslo: Gyldendal, 1973.

Publisert: 30. oktober 2012. Tidsskr Nor Legeforen. DOI: 10.4045/tidsskr.12.10o8

(C) Tidsskrift for Den norske legeforening 2023. Lastet ned fra tidsskriftet.no 26. april 2023. 